\title{
Training didactische vaardigheden tijdens studie. Niet zinvol*
}

\author{
T.A.W. Splinter
}

De onderwijswereld roert zich hevig. Het gemeenschappelijke onderwerp van aandacht is de verschuiving van 'docentgericht' naar 'studentgericht' onderwijs. Deze verschuiving herkent men aan termen zoals het zeer populaire 'problem based learning', 'e-learning', 'competentiegericht leren', 'portfolio's', 'feedback', 'leerstijlen', 'reflectie', etc. Een jonge, groene tak aan deze vernieuwingenboom is het voorstel om medisch studenten tijdens hun basisopleiding te trainen in didactische vaardigheden.

In dezelfde periode als waarin deze onderwijskundige roerselen zich voordoen, is het vak geneeskunde buiten proporties gegroeid door de enorme inbreng van nieuwe kennis over moleculaire biologische, farmaceutische producten en technologie, wat zelfs leidt tot hele nieuwe vakken. De student komt naar het universitair medisch centrum om kennis te verwerven van dit niet meer te overziene vak. Dat gebeurt op 'gatenkaasniveau', het geïntegreerd leren oplossen van medische problemen op 'basisniveau'.

Van medisch docenten wordt daarom verwacht dat zij studenten leren om patiëntencasussen op te lossen. Zij zijn in de eerste plaats medisch experts, die met enthousiasme en zonder pieper in staat zijn studenten te boeien en hun de echt moeilijke onderdelen van de geneeskunde te leren, zoals problemen begrijpen en oplossen. Van studenten wordt verwacht dat zij deficiënties in hun kennis herkennen en wegwerken, en dat zij actief en zelfstandig kennis vergaren.

De bestaande kwalificaties van universitair docent, universitair hoofddocent en hoogleraar berusten op het uitgangspunt dat zij op verschillend niveau experts zijn in hun vakgebied. Op basis hiervan en van hun didactische vaardigheden hebben zij inzicht in de manier waarop studenten vakinhoudelijke zaken wel of niet begrijpen en hoe zij deze voor studenten toegankelijk kunnen maken. ${ }^{1}$ Bij studenten ontbreekt deze vakinhoudelijke expertise nog in grote mate en mede daarom is het aanleren van didactische vaardigheden tijdens de studie prematuur. Aanleren hiervan 'voor de toekomst' heeft weinig zin. Vaardigheden die niet toegepast en onderhouden worden, verdwijnen weer. En voor de veronderstelling dat men een betere basisarts wordt door het aanleren van didactische vaardigheden, ontbreekt elk bewijs.

De verschuiving van 'docentgericht' naar 'studentgericht' komt voort uit de reactie op de autoritaire docent die meende te weten wat goed was voor de leerling. Opvallend is dat deze verschuiving gebaseerd is op 'geloof' en niet op 'bewijs'. Zelfevaluaties en tevredenheidsverklaringen van studenten, kwalitatief onderzoek en uitkomsten van focusgroep-

\footnotetext{
* Dit artikel is ook verschenen in het Nederlands Tijdschrift voor Geneeskunde (Ned Tijdschr Geneeskd. 2009;153:B292)
} 
gesprekken zijn niet bruikbaar als bewijs dat de invoering van een onderwijskundig nieuwigheidje de opleiding verbetert. Ik verwijs hier naar het rapport van het parlementaire onderzoek naar onderwijsvernieuwingen. $^{2}$ Een combinatie van onderwijskundig geloof en politiek winstbejag leidde tot een langdurig en ongecontroleerd experiment met jonge kinderen zonder protocol en toestemming van een onafhankelijke ethische commissie. De onderzoeksmuis is in Nederland beter beschermd.

Kortom, medisch studenten moeten getraind worden in het ontwikkelen van expertise en mogen pas docent worden als zij echt voldoende kunnen en weten om iets bij te dragen aan de ontwikkeling van studenten en artsen in opleiding tot specialist. Training in didactische vaardigheden lijkt wel leuk, maar laten we eerst onderzoeken of dat bijdraagt aan het doel van de geneeskundeopleiding. Het introduceren van oplossingen voor niet goed gedefinieerde problemen kan zelfs desastreus zijn.

\section{Literatuur}

1. Van Driel JH. Van een lerende vakdocent leer je het meest [oratie]. Leiden: Universiteit Leiden; 2008 .

2. Dijsselbloem JR. Parlementair onderzoek onderwijsvernieuwing. Deel I. Tweede Kamer, vergaderjaar 2007-2008. 's-Gravenhage: Sdu; 2008.

De auteur:

Prof. dr. T.A.W. (Ted) is internist, Erasmus MC, afd. Inwendige Geneeskunde, Rotterdam.

Correspondentieadres:

Prof.dr.T.A.W. Splinter, e-mail:t.splinter@erasmusmc.nl.

Belangenconflict: geen gemeld

Financiële ondersteuning: geen gemeld 